Technological University Dublin

DÜBLIN

ARROW@TU Dublin

\title{
Challenges and Opportunities Brought to the Chinese Economy by Brexit and the New US Administration
}

\author{
Lucia Morales \\ Technological University Dublin, lucia.morales@tudublin.ie \\ Bernadette Andreosso-O'Callaghan \\ University of Limerick
}

Follow this and additional works at: https://arrow.tudublin.ie/buschacart

Part of the Accounting Commons, Business Administration, Management, and Operations Commons, and the International Business Commons

\section{Recommended Citation}

Morales, L., \& Andreosso-O'Callaghan, B. (2019). Challenges and Opportunities Brought to the Chinese Economy by Brexit and the New US Administration. Journal of Emerging Market Finance, 18(2), 145-171. DOI: $10.1177 / 0972652719846304$

This Article is brought to you for free and open access by the School of Accounting and Finance at ARROW@TU Dublin. It has been accepted for inclusion in Articles by an authorized administrator of ARROW@TU Dublin. For more information, please contact arrow.admin@tudublin.ie, aisling.coyne@tudublin.ie, gerard.connolly@tudublin.ie.

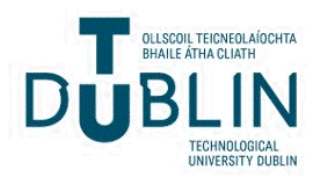




\section{Challenges and Opportunities Brought to the Chinese Economy by Brexit and the New US Administration}

Journal of Emerging Market Finance I8(2) 145-I7I, 2019

(C) 2019 Institute for Financial Management and Research Reprints and permissions: in.sagepub.com/journals-permissions-india DOI: I0.I I77/09726527|9846304 journals.sagepub.com/home/emf

(S)AGE

\title{
Lucía Morales'
}

\section{Bernadette Andreosso-O'Callaghan ${ }^{2,3}$}

\begin{abstract}
The impact of Brexit and the election of Donald Trump as the 45th US president in the context of stock market reactions and economic policy uncertainty (EPU) within three key zones in 'the Greater China Region' (Hong Kong, Taiwan and China Mainland) are examined in this article. The chosen research period is from January 2014 to June 2017, and the EPU Index in the USA and the UK is used as a proxy to measure political uncertainty in two of the world major economies and how they impact on the Chinese stock market. The main contribution of the article can be found in the analysis of how stock market performance can be driven by policy-related uncertainty shocks in the international context. The results show that the stock markets in the 'Greater China Region' did not seem to react either to the uncertainty generated by Brexit or to the election of Donald Trump, implying that the Chinese stock markets appear to be quite resilient to the recent political events that have been disrupting the global economy.
\end{abstract}

\footnotetext{
I Technological University Dublin, Dublin, Ireland.

${ }^{2}$ University of Limerick, Limerick, Ireland.

${ }^{3}$ Ruhr Universität Bochum, Bochum, Germany.
}

\section{Corresponding author:}

Lucía Morales, Technological University Dublin, Dublin, Ireland.

E-mail: lucia.morales@dit.ie 


\section{Keywords}

Brexit, Trump, China, stock markets, economic policy uncertainty

JEL codes: G58, GI5, GI8

\section{Introduction}

From the 1970s, researchers have identified political risk as a significant factor that can severely disturb the performance of developing and emerging countries (Benacek, Lenihan, Andreosso-O'Callaghan, Michalikova, \& Kan, 2014; Suleman, 2012). Earlier explanations in the field suggest that political events can cause a significant loss of wealth that can also trigger increases in stock market volatility (Brewer, 1981; Clark, 1997; Clark \& Tunaru, 2003; Root, 1972; Simon, 1982). The magnitude and relevance of materialised losses are also linked to unfolding political events that can subsequently spill over to the rest of the economy by the generation of economic and financial uncertainty (Clark \& Tunaru, 2005). Recent political events, in a macroeconomic context, such as the UK's decision to leave the European Union (EU) in June 2016 and the election of Donald Trump as the 45th President of the USA signify important changes to the world economies. As we are moving into a new area of remarkable ambiguity, global economic stability and growth are being challenged once more. Trump's initial approach to international relations with China has been creating significant levels of confusion and concern among leaders in Beijing. During his campaign, the candidate made serious accusations against China, with messages stating that China was a currency manipulator and that it was stealing millions of jobs from the US economy. Furthermore, he beckoned the need of getting a new deal from China that in view of his inexperience in foreign affairs has just been contributing to making the situation more chaotic and that seems to be leading towards a commercial antagonism between the two countries. Concern has been raised around Trump's intent of renegotiating some of the existing trade treaties and of introducing tariffs on Chinese goods of up to 45 per cent, threats that have now become a reality with the introduction of tariffs on Chinese steel and aluminium imports. Analysts are indicating that the Trump's administration might harden tax imports, and that the alleged currency manipulation in China would justify the introduction of protectionist measures. However, as the situation unfolds, Chinese authorities and the international community are quite unsure of what to expect from the US 
new President's initial comments, and countries are starting to retaliate. At the same time, the UK new Prime Minister, Theresa May, is trying to redefine the UK's relations with countries, such as China, with the aim of ensuring that an optimal balance between the economic and political dimension be kept. The development of a coherent strategy emanating from London that looks to build on a sustainable strategy towards China seems to be another source of ambiguity and uncertainty. In general, analysts' views are quite mixed, with some suggesting that China could be a clear winner, and others a loser from the Trump and Brexit situation. Hence, the main motivation of this research article is twofold:

- to identify the main challenges and opportunities that the new US President and Brexit events are bringing to the Chinese economy in terms of its international position.

- to examine China's strategic moves to deal with the uncertainty created by Trump's election and Brexit on its economic growth and development and its strategic position in the Pacific region.

To illustrate the points outlined earlier, this article examines whether the financial markets of Hong Kong, Taiwan and Mainland China reacted in a similar or different fashion to Brexit and to Trump's election. The analysis is supported by the use of the Economic Policy Uncertainty (EPU) Index for the USA and the UK, with the aim of measuring market instability over the period and implications for the selected stock markets. To the best of the authors' knowledge, this study would be the first attempt to analyse how Brexit and the recent US Presidential election impacted on the stock markets of the Greater China Region, which refers to Mainland China, Taiwan, Hong Kong and Macau. ${ }^{1}$

\section{Brexit and the New US Administration: Implications for 'The Greater China Region'}

The world is facing challenging times, as the balance of regional power is shifting with emerging economies taking more prominent roles, while developed economies seem to be deploying anti-globalisation and protectionist policies (Tanaka, 2017). For several advanced economies, the scenario is one where a surge of populism accompanies a sentiment of anti-free trade, a phenomenon that has clearly been illustrated by both the UK Brexit referendum and the election of Donald Trump as the President of 
the USA in 2016. When looking at emerging economies, the case of China can be considered as outstanding. China has undergone rapid economic growth over the past three decades, and in 2011, China's GDP overtook that of Japan, and the country became the second largest economy in the world. However, years of double-digit growth have given way to a new model that is considered as the new normal and which has refocused to target annual growth rates at around 6.5 per cent. This level of growth could be affected if the Trump's administration takes a more hostile approach towards China, and this could unfold into a trade antagonism that would damage the interests of the country as well as those of the East Asian region as a whole. As China is benefiting from globalisation, and its global and regional power keeps increasing, the study of how the Greater China Region might be impacted upon by an increase of market uncertainty triggered by recent political events originating in two of the world most developed economies is of key interest. An analysis of policy uncertainty combined with stock markets performance will offer an initial view on how the Greater China Region reacted to the uncertainty created by the new political wave.

China is considered as an export-intensive economy by global standards, whose economic projections are heavily linked to the strength and health of world trade. As a result, recent geopolitical events are a source of major concern to Chinese policymakers. President Trump's policies and views towards China need to be closely monitored, as the USA is one of China's key trading partners, a situation that came to light with the 2008 Global Financial Crisis. If Trump's plans to introduce tariff barriers targeting China (of $45 \%$ on Chinese imports) materialise, Chinese total exports will be significantly affected in the short term, given that around 20 per cent of the country's total exports are bound to the US economy. The situation is further convoluted by the uncertainty that surrounds the Trump's administration economic policy programme. Moreover, the case of Brexit is also a major area of concern, but in this case, China might be able to weather a negative impact on its economy in the short term, as China exports to the UK account only for 2.5 per cent. However, in the medium to long term, the implications would be more important, as the departure of the UK from the EU could signify a change in direction regarding trade policies from the EU towards emerging markets regions. Bearing in mind that the UK has traditionally been representing one of the most liberal-minded trading economies in the EU, its departure from the EU could make the materialisation of a deeper China-EU economic deal (a long-term objective) quite difficult. Additionally, a chaotic Brexit where trade and investment are significantly disrupted will cause a 
knock-on effect in the Eurozone with clear ramifications in China. The industrial sectors that will clearly be affected are chemicals, machinery and consumer-based sectors since China exports around 15-20 per cent of its global total to Europe. Therefore, the UK's decision to leave the EU can damage China's global position in the long term, as the country could be left in a remarkable vulnerable position. China's strong commitment to export activities makes the country quite susceptible to the potential upsurge in protectionist measures that are being sought by major advanced economies.

Examining the impact of Brexit and Donald Trump's election on the performance of the main stock markets in the Greater China Region will offer an initial view on how the country is reacting to global uncertainty. The stock markets of Mainland China, Taiwan and Hong Kong are considered to be quite different regarding their levels of political freedom, the fairness of their political system and the level of centralisation in terms of their political and economic approach and also in terms of the level of market intervention. Mainland China is characterised by a more rigid and centralised model with heavy political control on its economic model. The region also exhibits the highest levels of economic growth. In contrast, Taiwan enjoys the highest level of political freedom of all four sub-markets while its economic and legal system seem to be fairer. Hong Kong is well known for its relatively non-interventionist economic policies, encompassing the freedom of capital movements and a well-developed regulatory and legal environment. These conditions have contributed to the development and consolidation of Hong Kong as a regional and international financial centre. Hong Kong Stock Exchange plays a major role in raising capital for Chinese state-owned enterprises (SOEs). Economic growth in Hong Kong is based on a free market economy with strong ties to international trade and finance, characteristics that left its economy significantly exposed to the 2008 Global Economic and Financial Crisis. However, due to its increasing level of integration with Mainland China, Hong Kong managed to execute a swift recovery from the global meltdown. However, its heavy reliance on foreign trade and investment is enhancing its vulnerability in the global context. Taiwan's economic model relies on an export-oriented approach like the one followed by Hong Kong. The main trading partner of Taiwan is Mainland China, which makes its economic and financial model quite exposed to external shocks and more specifically to disruptions originating from China. This entails that Taiwan is more sensitive to regional issues rather than to global and international events. This is illustrated by the economic slowdown faced by Taiwan that can be somehow explained by the economic deceleration experienced by China 
over the past few years with its transition from a double-digit growing economy to a new normal growth model. In the international context, Taiwan's economic relations with the USA keep improving, as the USA is Taiwan's second largest trading partner and its main source of foreign direct investment (Rosier, O’Connor, \& Cuevas, 2016).

\section{Political Events, Policy Uncertainty and Stock Market Reactions}

Political events and, in particular, the impact and implications that political risk might have on the performance of stock markets are the areas of research that do not seem to attract the same amount of attention as the risks associated with asset pricing, market (systemic) risk, interest rate risk, exchange rate risk or credit risk (Bilson, Brailsford, \& Hooper, 2002). Furthermore, the case of emerging markets - and especially of those markets that are characterised by a rigid and less liberal approach in their economic and/or political regimes - is commonly associated with greater levels of uncertainty (Benacek et al., 2014; Bin, 2015). Political stability is an area of concern for a country's economic and financial performance because a political environment that is predictable and reliable offers a favourable environment for investors who perceive the economy to be less risky (Manzoor, 2013). Unstable political situations have been associated with a significant reduction in foreign direct investment as the market is not considered safe, and economic and financial activities might not be properly controlled and monitored, with potential failures in terms of law compliance and transparency of operations (Chan \& Wei, 1996). Furthermore, developing economies that face disruptions due to an unstable political climate appear to be more affected by macroeconomic imbalances that lead to greater levels of risk rather than to disruptions with origins in international events (Aggarwal, Inclan, \& Leal, 1999; Khalid \& Rajaguru, 2010).

Research exploring the implications of political risk on market performance seems to be focused on the analysis of political news and the way financial markets react to them. In particular, stock markets seem to be more responsive to new information regarding political decisions rather than to information that looks into implications and spillover effects of domestic and foreign policy. According to Tan and Gannon (2002), the reaction of the stock market depends on the political news, with prices expected to increase if the news lead to an upward revision of investor's expectations and prices following a downward trend if the opposite occurs. Researchers have followed different approaches when looking at political 
events and analysing market reactions. For instance, Soultanaeva (2008) used political news as a proxy to analyse political risk and found a weak relationship between political risk and the volatility of the stock market. Fong and Koh (2002) looked at the Hong Kong stock market and how political risk has induced a regime shift in stock market volatility with a strong evidence found in terms of regime shift in conditional volatility as well as significant volatility asymmetry during highly volatile periods.

Mahmood, Irfan, Iqbal, Kamran, and Ijaz (2014) examined 50 major political events in Pakistan and their impact on the KSE-100 index returns with the aim of illustrating how political events contribute to increased levels of economic risk in the context of a less developed economy that might be more reactive to unstable political conditions when compared to developed economies (Bittlingmayer, 1998). Research findings show that the Pakistani stock market reacts to political events and that, as a result, investors are quite hesitant to participate in this market. The case of Pakistan is an interesting one as its political environment has been quite unpredictable over the past 50 years; this has been characterised by the inability of any elected government to complete their 5-year mandate. Colombia is another example of a less developed economy that has been examined and that shows how market returns are negatively influenced by criminal activities and an uncertain political environment (Laverde, Varua, \& Garces-Ozanne, 2009). Researchers have found that political stability conditions might contribute to accelerate long-term growth projections. On the other hand, research outcomes focusing on developed economies seem to offer a different view regarding the magnitude and implications that political uncertainty might bring to stock markets performance. For example, Dopke and Pierdzioch (2006) looked at the performance of the German stock exchange and they found a poor relationship between political changes and stock market performance.

The conducted literature review shows that most of the research in the field seems to be looking at the impact on internal/domestic political events with little attention given to external and global shocks in the context of developing and emerging economies. As a result, a research gap has been identified in the area, and considering recent developments in the international political arena, this study is bringing a clear contribution to this area.

\section{I Economic Policy Uncertainty}

EPU refers to a non-zero probability of changes in the existing economic policies that determine the rule of the game for economic agents 
(Baker, Bloom, \& Davis, 2012, 2016). EPU can impact upon economic and financial agents in different manners: (a) firms may change or delay investment decisions depending on the levels of employment, consumption and savings; (b) production costs might be affected, and investment patterns can change depending on the economic cycle; and (c) risks in financial markets can be impacted as inflation rates, interest rates and expected risk premiums will vary depending on EPU. Recent economic and political events have increased researchers' interests in understanding the economic impact of policy uncertainty (Bloom, 2009). In particular, the implications of EPU for financial risk management and the implications for stock market performance is an area of study that is not much developed with most of the existing research focusing on the analysis of market performance over the last two or three decades (Anatonakakis, Chatziantoniou, \& Filis, 2013; Brogaard \& Detzel, 2015; Kang \& Ratti, 2015; Li \& Peng, 2017; Liu \& Zhang, 2015). The extant literature shows significant evidence that EPU does confound market participants and policymakers, in terms of financial risk. Li and Peng (2017) showed that the absolute changes in the US EPU index have a negative impact on the co-movement of the domestic market. Another recent study looking at policy uncertainty and implications for the US stock market volatility by Arouri, Estay, Rault, and Roubaud (2016) shows that an increase in policy uncertainty reduces in a significant manner stock returns and that the effects become stronger and persistent during times of extreme market volatility. However, to the best of the authors' knowledge, the implications of Brexit and of the new US administration combined with the analysis of EPU and implications for the Greater China Region is an area of research that has not being addressed as yet. Moreover, the recent literature in the area (Hammoudeh $\&$ McAleer, 2015) highlights how the topic of financial risk management and its connections to policy uncertainty is a topic widely researched, cited and downloaded, justifying thereby the need for further empirical contributions in the area.

\section{Data Description and Methodological Framework}

The data chosen to support this study is based on daily time series of stock market indices downloaded from DataStream. The Standard and Poor's 500 index and the FTSE 100 index are selected as proxies for stock market behaviour that take into account political instability in the USA and the 
UK. The Taiwan Stock Exchange (TSE composite Index), the Hong Kong's Hang-Seng index and the Shanghai Security Exchange SSE composite indices are selected to measure stock market performance in the Greater China Region. The selected sample covers the period from January 2014 to June 2017. To control for political instability, the policy uncertainty index is also included as part of the study. The US EPU index and the UK EPU index are obtained from the EPU website. The EPU indices are computed on the basis of daily news from newspaper archives that contain thousands of newspapers and other news sources from across the globe. Studies using Baker's et al. (2012) EPU measures found that the indices are a good proxy for real-world economy policy uncertainty (Wang, Chen, \& Huang, 2014). Consequently, this study also considers EPU as a variable that will help us adjust our models with the aim of creating a stronger filter for the political events under consideration.

\section{I Brexit Highlights}

Back in June 2016, the UK voters chose to leave the EU, and soon afterwards, they welcomed their new Prime Minister Theresa May. The Prime Minister confirmed the exit of the UK from the EU by triggering Article 50 of the Lisbon Treaty on 29 March 2017. For the purpose of this study, the Brexit event timeline needs to be considered, as it will determine how the dummy variables that look after Brexit are constructed.

Figures 1 and 2 offer a general overview on the behaviour of the EPU indices close to the outcome of the UK referendum and the US

Table I. Year 2016

\begin{tabular}{lllll}
\hline June 23 & June 24 & June 25 & June 28 & June 30 \\
\hline UK holds a & Referendum & Jonathan Hill & German & Theresa May \\
referendum & results: 52\% & resigns as & Chancellor & declares \\
on whether & voters chose & EU financial & Angela & candidacy \\
to leave EU & to leave EU & services chief & Merkel & for the \\
& & & informs & Conservative \\
& & Cameron of & party \\
& & & no 'cherry & \\
& & & picking and & \\
& & & no informal & \\
& & & &
\end{tabular}

(Table I continued) 
(Table I continued)

\begin{tabular}{|c|c|c|c|c|}
\hline July 5 & July 8 & July I3 & July 26 & July 27 \\
\hline $\begin{array}{l}\text { Three of the } \\
\text { UK's largest } \\
\text { real-estate } \\
\text { funds freeze } \\
\text { assets after } \\
\text { Brexit vote } \\
\text { due to the } \\
\text { burst of } \\
\text { redemptions }\end{array}$ & $\begin{array}{l}\text { Julian King } \\
\text { replaces } \\
\text { Jonathan } \\
\text { Hill as head } \\
\text { of financial } \\
\text { services }\end{array}$ & $\begin{array}{l}\text { Theresa May } \\
\text { becomes } \\
\text { Prime } \\
\text { Minister }\end{array}$ & $\begin{array}{l}\text { The Financial } \\
\text { Times } \\
\text { Reports that } \\
\text { Fox wants the } \\
\text { UK to leave } \\
\text { Europe's } \\
\text { custom union }\end{array}$ & $\begin{array}{l}\text { Theresa May } \\
\text { says the UK's } \\
\text { future trade } \\
\text { relationship } \\
\text { with the EU } \\
\text { should not be } \\
\text { 'a model on the } \\
\text { shelf already' }\end{array}$ \\
\hline November 4 & November 21 & November 23 & November 24 & November 29 \\
\hline $\begin{array}{l}\text { Newspapers } \\
\text { criticise the } \\
\text { High Court } \\
\text { Judges }\end{array}$ & $\begin{array}{l}\text { Trump } \\
\text { tweets that } \\
\text { Nigel Farage } \\
\text { of the UK } \\
\text { Independence } \\
\text { Party would } \\
\text { 'do a great } \\
\text { job' }\end{array}$ & $\begin{array}{l}\text { Hammond } \\
\text { delivers his } \\
\text { budget and } \\
\text { estimates that } \\
\text { as a result } \\
\text { of Brexit the } \\
\text { government } \\
\text { will need to } \\
\text { borrow an } \\
\text { extra } 58.7 \\
\text { billion pounds }\end{array}$ & $\begin{array}{l}\text { Former Prime } \\
\text { Minister } \\
\text { Tony Blair } \\
\text { says Brexit } \\
\text { deal can be } \\
\text { stopped if } \\
\text { it does not } \\
\text { 'stack up' }\end{array}$ & $\begin{array}{l}\text { European } \\
\text { Council } \\
\text { President } \\
\text { Donal Tusk } \\
\text { tells UK } \\
\text { lawmakers } \\
\text { that Brexit } \\
\text { is creating } \\
\text { 'anxiety and } \\
\text { uncertainty' }\end{array}$ \\
\hline
\end{tabular}

Source: The authors.

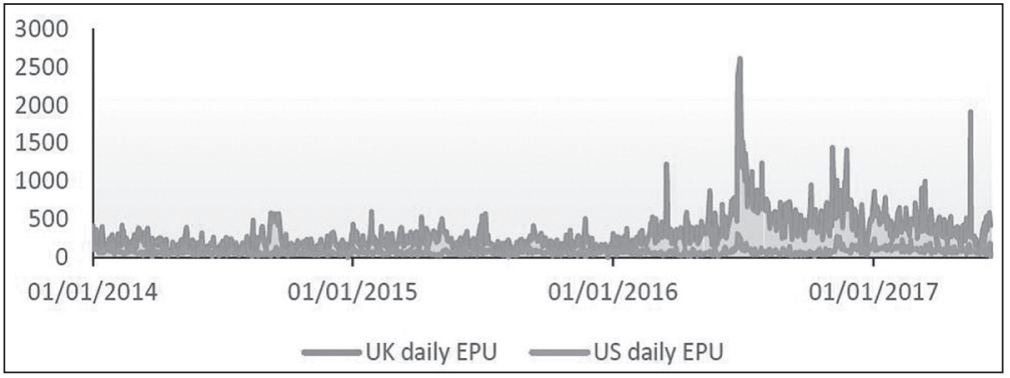

Figure I. Economic Policy Uncertainty Indexes

Source: The authors. 


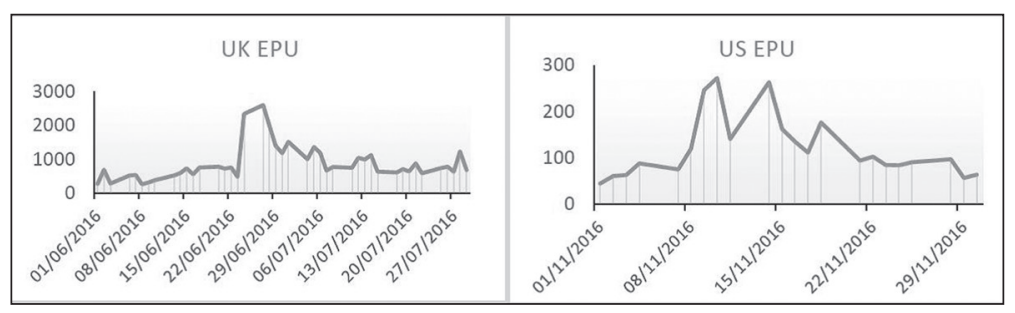

Figure 2. UK and US EPUs Evolution Around Events Date

Source: The authors.

election. The indices show a relative stability before the events outcome is released with interesting developments in both countries that seem to reflect a level of persistence regarding uncertainty that lasted at least over a week before the indices revert to more stable levels. The EPU indices are used in this study to delimit the range of the dummy variables to measure for Brexit and Trump's election uncertainty. Values of 1 are given to the date when the UK referendum results were released (24 June 2016) and the announcement of Trump's election as the 45th US president ( 8 November 2016). The dummy variables help to delimit two scenarios, one looking at a week of market uncertainty and another looking at a prolonged period that considers the aftermath of each one of the events until June 2017.

Table 2. Year 2016

\begin{tabular}{lllll}
\hline February I & March I & March II & May 3 & May 26 \\
\hline $\begin{array}{l}\text { Trump comes } \\
\text { second in }\end{array}$ & $\begin{array}{l}\text { Trump wins } \\
\text { 7 of the II }\end{array}$ & $\begin{array}{l}\text { Trump } \\
\text { continues to }\end{array}$ & $\begin{array}{l}\text { Trump wins } \\
\text { Indiana and }\end{array}$ & $\begin{array}{l}\text { Trump wins } \\
\text { a majority }\end{array}$ \\
the lowa & states that & draw huge & becomes the & of delegates \\
caucuses & vote on so- & crowds, & Republican & securing his \\
& called Super & and a rally & Party's & nomination \\
& Tuesday & in Chicago & presumptive & and foreclosing \\
& & had to be & nominee & the possibility \\
& & cancelled due & & of a contested \\
& & to violent & & convention \\
& protests & &
\end{tabular}

(Table 2 continued) 
(Table 2 continued)

\begin{tabular}{|c|c|c|c|c|}
\hline June 20 & July I5 & September I & $\begin{array}{l}\text { September/ } \\
\text { October }\end{array}$ & November 8 \\
\hline $\begin{array}{l}\text { Trump fires } \\
\text { his original } \\
\text { campaign } \\
\text { manager, } \\
\text { Corey } \\
\text { Lewandowski } \\
\text { and veteran } \\
\text { republican } \\
\text { strategist } \\
\text { Paul Manafort } \\
\text { takes over }\end{array}$ & $\begin{array}{l}\text { Trump } \\
\text { announces } \\
\text { Indiana } \\
\text { Governor } \\
\text { Mike Pence } \\
\text { as his running } \\
\text { mate }\end{array}$ & $\begin{array}{l}\text { Trump flies } \\
\text { to Mexico } \\
\text { to meet with } \\
\text { the country's } \\
\text { President } \\
\text { Enrique Peña } \\
\text { Nieto. A brief } \\
\text { diplomatic } \\
\text { scuffle follows } \\
\text { regarding } \\
\text { Trump's views } \\
\text { on Mexico to } \\
\text { pay for the } \\
\text { border wall }\end{array}$ & $\begin{array}{l}\text { Trump } \\
\text { clashes with } \\
\text { Clinton } \\
\text { before an } \\
\text { audience } \\
\text { on tens of } \\
\text { millions } \\
\text { in three } \\
\text { presidential } \\
\text { debates }\end{array}$ & $\begin{array}{l}\text { Trump wins } \\
\text { US presidential } \\
\text { election }\end{array}$ \\
\hline
\end{tabular}

Source: The authors.

\subsection{US Elections Highlights}

The Chinese stock market reaction to Brexit and Trump's election is measured by the identification of abnormal mean returns and also by looking at the potential shift in returns volatility. The research framework is supported by three different models that are discussed in the following sections.

\subsection{Model One}

The first part of the study examines the potential existence of abnormal mean returns by implementing a multivariate regression model (MVRM) that aligns to the approach proposed by Bin, Blenman, and Chen (2004), Kim, Nam, and Wynne (2009) and Nazir, Younus, Kaleem, and Anwar (2014). The main purpose of this model is to identify a system of portfolio return equations for event announcements with systematic risk and political events being factored into the pricing process. Equation (1) is the generic equation that would be adjusted according to the event under study (Trump election or Brexit referendum) and that would be captured by the inclusion of a dummy variable in the model.

$$
R_{i, t}=\alpha_{i}+\beta_{i} R_{m, t}+\delta \text { Dummy }_{i, t}+\varepsilon_{i, t}
$$


where

$R_{i, t}=$ return on a Greater China Region (GCR) market index $i$ on day $t$. $\alpha_{i}=$ intercept coefficient for GCR index.

$\beta_{i}=$ coefficient of sensitivity to the Trump's election or to Brexit.

$R_{m, t}=\mathrm{S} \&$ P500 return or FTSE 100 return, depending on the event under consideration.

Dummy $=$ dummy variable that equals 1 during the window period that considers the event under study (Trump or Brexit) and 0 otherwise.

$\delta=$ price return reaction to the political event on the corresponding GCR index $i$.

$\varepsilon_{i, t}=$ an independent and identically distributed normal error.

The study is supported by the seemingly unrelated regression (SUR) methodology on daily returns over the 253 and 156 trading days around the identified leadership event windows (Brexit referendum result and US presidential election respectively). Additionally, the estimation is supported by daily returns over a week after the event under study in order to consider short-run implications. In this way, the jointly estimate of the abnormal mean return performance of the three GCR indices is considered over a short-time period that is very close to the political event under study and also over a longer period of sustained market and EPU. As such, the research hypotheses under consideration are as follows:

Hypothesis A: $\delta=0$-Meaning that the estimated abnormal return for each one of the three GCR market indices equals zero when the corresponding event-leadership event (Trump's election or Brexit) occurs.

The model is adjusted to consider the implications of EPU, and as a result, the initial regression equation presented in Equation (1) is adjusted as follows:

$$
R_{i, t}=\alpha_{i}+\beta_{i} R_{m, t}+\delta \text { Dummy }_{i, t}+\theta E P U_{i, t}+\varepsilon_{i, t}
$$

Hypothesis B: $\theta=0-$ Meaning that international economic political uncertainty does not generate an impact on the three GCR market indices.

The model is estimated to test again for: $\delta=0$, with the aim of verifying if there is a significant change on the outcomes once the EPU index is introduced in the model estimation. 
Liu and Zhang (2015) showed that incorporating EPU as an additional variable in the implementation of volatility prediction models significantly improves their forecasting ability. Therefore, our decision of including EPU as part of our research framework is more than justified as we aim to cross-check our results and to analyse if the introduction of EPU in the model brings different and significant results confirming the importance of EPU for stock market performance.

\subsubsection{Model Two}

Model one was adjusted to introduce four control variables that seek to find out if there are variations regarding the outcomes of EPU as outlined in Equation (2). The initial regression model presented in Equation (1) above is adjusted once more to integrate the selected control variables. A note of caution is needed here, as there were limitations regarding the control variables associated with market uncertainty that could not be considered as part of this study due to their unavailability as daily frequency variables. For example, relevant economic indicators for China were not considered as there were no data available in DataStream with a daily frequency. A similar situation was faced when trying to integrate additional indicators for EPU like Global economic uncertainty or Chinese economic uncertainty, as available data were found in monthly frequency. After careful consideration of the variables that could improve the model, four additional indexes were considered. The selected control variables were as follows: (a) the volatility index (VIX) that was included as a variable that helped to capture market sentiment over the period of study, as it is considered as a good estimator of expected market volatility; (b) the Hong Kong volatility index (HSI Volatility Index) is an indicator of the volatility exhibited by the Hong Kong Stock market, and it is considered as the premier barometer for investor sentiment; (c) the Chinese 3-month repo rate (China-3mRepo rate) is the interbank rate on short-term loans between banks in local currency and that seeks to measure for market instability derived from access to liquidity and the fourth control variable was the Chinese Renminbi 3 month FX volatility variable to capture instability in the currency market. Equation (3) considers the additional model to be estimated.

$$
R_{i, t}=\alpha_{i}+\beta_{i} R_{m, t}+\delta \text { Dummy }_{i, t}+\theta E P U_{i, t}+\gamma \text { Control }_{i, t}+\varepsilon_{i, t}
$$




\subsubsection{Model Three}

The third phase of the estimation process considers market volatility employing the 'Generalised Autoregressive Conditional Heteroscedasticity' GARCH framework, with the objective of examining the effects that the chosen events will have on volatility performance in the corresponding GCR stock index returns. The Exponential GARCH model introduced by Nelson (1991) allows to analyse the impact of 'good and bad news' on volatility. The EGARCH $(1,1)$ is chosen on the grounds that this model does not have constraints regarding 'non-negativity' of its parameters (Bin, 2015; Lin \& Wang, 2005; Suleman, 2012). The EGARCH model is defined as follows:

$$
\begin{gathered}
\log \left(\sigma_{t}^{2}\right)=\omega+\alpha f_{t}\left(z_{t-1}\right)+\beta \log \left(\sigma_{t-1}^{2}\right) \\
f_{t}\left(z_{t-1}\right)=\left(\left|z_{t-1}\right|\right)-E\left|z_{t-1}\right|+\gamma z_{t-1}
\end{gathered}
$$

where

$$
z_{t-1}=\epsilon_{t-1} / \sigma_{t-1}
$$

$\alpha, \beta$ and $\gamma$ are parameters for the conditional variance estimation. The alpha coefficient explains the influence of past standardised residuals on current volatility. The beta coefficient measures the impact of past-period variance on the current period conditional variance. The gamma coefficient accounts for the asymmetry effect. If gamma is negative, it will signify that bad news have a greater impact on volatility than good news with the same magnitude. The EGARCH models the logarithmic time-varying conditional variance; consequently, these models allowed its parameters to become negative. As a result, the model is not subject to non-negativity constraints in the parameters as it is the case for the traditional GARCH and GJR models. However, in order to meet stationary requirements, the beta coefficient should be less than one $(\beta<1)$. Since the gamma coefficient looks at asymmetric effects, the coefficient would be equal to zero if positive and negative shocks have an equal impact on the variance. If the magnitude of a negative (positive) shock causes the variance to increase (decrease), the gamma coefficient will be lower than zero $(\gamma<0)$. In the case that positive (negative) shocks cause the variance to increase (decrease), the gamma coefficient would be greater than zero $(\gamma>0)$. 
Table 3. EGARCH Stationarity Restriction

\begin{tabular}{|c|c|c|}
\hline Coefficients & Meaning & Implications \\
\hline$\alpha$ & $\begin{array}{l}\text { Represents the magnitude } \\
\text { effect or the symmetric } \\
\text { effect of the model, the } \\
\text { GARCH effect. }\end{array}$ & $\begin{array}{l}\text { The coefficient measures the } \\
\text { effect of the previous period in } \\
\text { the information set and explains } \\
\text { the past standardised residuals' } \\
\text { influence on the current volatility. }\end{array}$ \\
\hline$\beta$ & $\begin{array}{l}\text { Measures the persistence } \\
\text { in conditional volatility } \\
\text { irrespective of anything } \\
\text { happening in the market - } \\
\beta<1\end{array}$ & $\begin{array}{l}\text { If beta is relatively large, volatility } \\
\text { takes a long time to die out }\end{array}$ \\
\hline$\gamma$ & $\begin{array}{l}\text { Measures the asymmetry } \\
\text { of the leverage effect. }\end{array}$ & $\begin{array}{l}\text { If } \gamma=0 \text {, the model is symmetric. } \\
\text { If } \gamma<0 \text {, positive shocks generate } \\
\text { less volatility than negative shocks. }\end{array}$ \\
\hline & & $\begin{array}{l}\text { If } \gamma>0 \text {, positive shocks are more } \\
\text { destabilising than negative news. }\end{array}$ \\
\hline
\end{tabular}

Source: The authors.

The variance equation considered in this study is outlined as follows:

$$
\begin{gathered}
\log \left(\sigma_{t}^{2}\right)=\omega+\alpha_{j} f_{t}\left(z_{t-1}\right)+\beta_{j} \log \left(\sigma_{t-1}^{2}\right)+\varphi D_{u m m y_{t}} \\
\log \left(\sigma_{t}^{2}\right)=\omega+\alpha_{j} f_{t}\left(z_{t-1}\right)+\beta_{j} \log \left(\sigma_{t-1}^{2}\right)+\varphi D_{u m m y_{t}}+\rho E P U_{t}
\end{gathered}
$$

Table 4. Series Descriptive Statistics

\begin{tabular}{lcccrr}
\hline $\begin{array}{l}\text { Descriptive } \\
\text { Statistics }\end{array}$ & Hong Kong & $\begin{array}{c}\text { Mainland } \\
\text { China }\end{array}$ & Taiwan & FTSE 100 & S\&P 500 \\
\hline Mean & 0.0116 & 0.0436 & 0.0174 & 0.0113 & 0.0307 \\
Standard & 1.0597 & 1.6138 & 0.7891 & 0.9103 & 0.7900 \\
deviation & & & & & \\
Skewness & -0.3468 & -1.3002 & -0.5128 & -0.1682 & -0.3834 \\
Kurtosis & 5.979707 & 9.8401 & 6.7502 & 5.6071 & 5.8693 \\
Jarque Bera & 350.9905 & 2008.131 & 566.8596 & 259.1380 & 330.8018 \\
Observations & 900 & 900 & 900 & 900 & 900 \\
\hline
\end{tabular}

Source: The authors. 


\section{Empirical Findings}

Descriptive statistics show that market returns over the period of study are positive for all cases with Mainland China exhibiting better performance followed by the S\&P500, while stock markets in Hong Kong and Taiwan seem to follow the overall performance of the FTSE100. The standard deviation signposts the Shanghai stock market as the most volatile over the period of study with the S\&P500 exhibiting lower fluctuations. All the markets are negatively skewed and exhibit kurtosis and non-normality.

The estimation of Equations (1) and (2) shows that the markets do not exhibit abnormal returns in any case. The models considered market uncertainty since the date of occurrence of each one of the events (Brexit and Trump's election) over a week and also over a longer period (up to June 2017). Furthermore, the inclusion of the EPU index and of the control variables did not affect the initial outcomes. The results indicate that Brexit and Trump's election did not lead to a significant increase in market uncertainty in the GCR. The research findings suggest that Chinese stock markets might be waiting for specific actions to be taken by the UK and US administration that show if they aim to harm China's interests. The results do not seem to align with research in the field that has suggested that the EPU index helps to identify if market participants are reacting to political events (Anatonakakis et al., 2013; Brogaard \& Detzel, 2015; Kang \& Ratti, 2015; Li \& Peng, 2017; Liu \& Zhang, 2015). The outcomes for the GCR seem to align with the study of Dopke and Pierdzioch (2006) which looks at the German stock market, where political changes showed a poor relationship with stock market performance. These outcomes indicate that Chinese stock markets might be maturing and that they start to exhibit patterns commonly associated with more developed and established stock markets. On the other hand, there is a need for highlighting the fact that Chinese stock markets are heavily prone to state intervention and that SOEs have a heavy representation among the listed companies.

The estimation of the EGARCH model confirms the non-existence of abnormal returns as the $\delta$ coefficient is insignificant in every case. The results show that Hong Kong and Taiwan are more affected by the occurrence of negative news as the $\gamma$ coefficient is negative and significant in every case. However, Mainland China differs, and the Shanghai stock market volatility seems to be more affected by positive news rather than by negative innovations. 


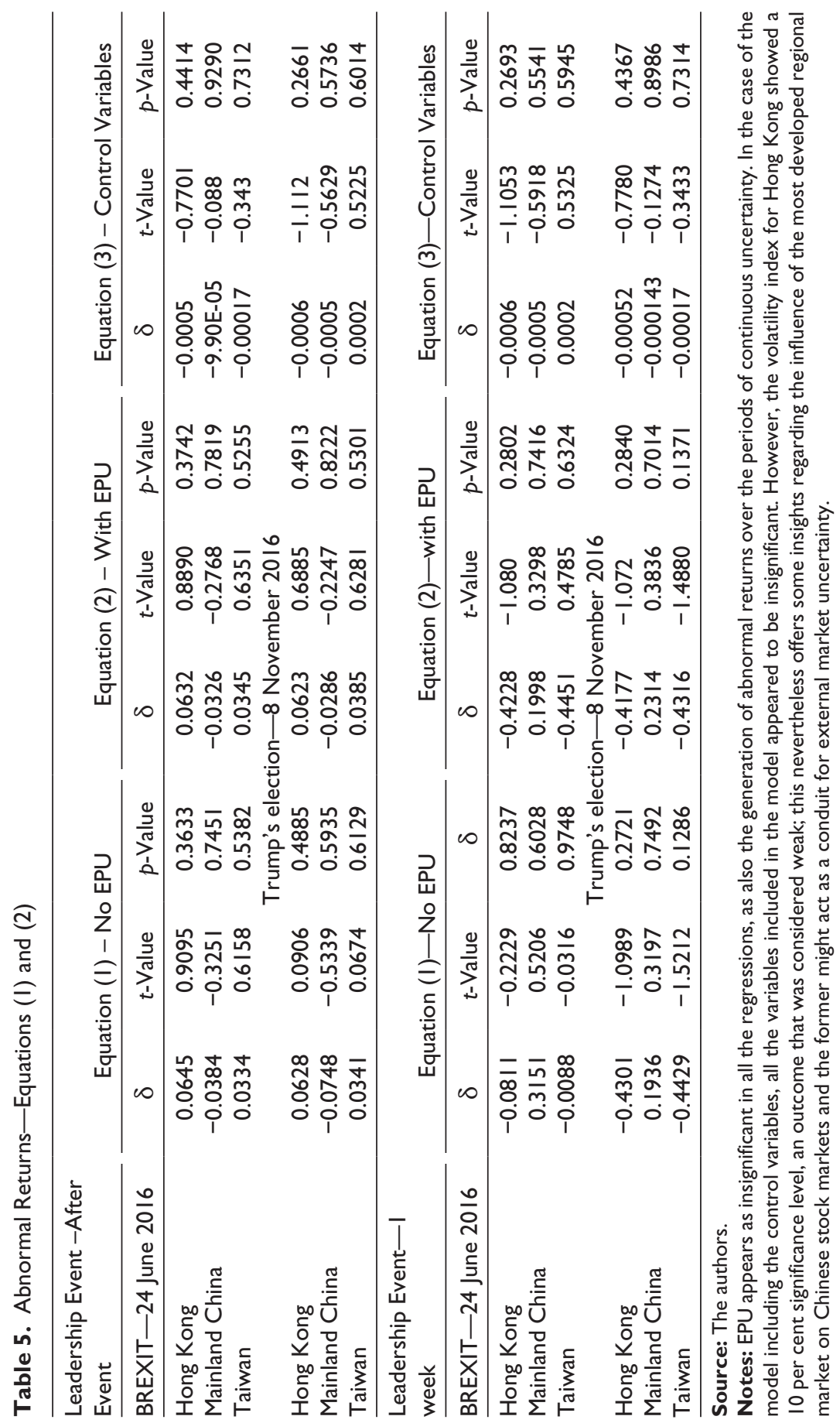


Table 6. Volatility Model Without Economic Policy Uncertainty

\begin{tabular}{|c|c|c|c|c|c|c|}
\hline \multirow{2}{*}{$\begin{array}{l}\text { Leadership } \\
\text { Event- } \\
\text { Without } \\
\text { EPU Index } \\
\text { Mean } \\
\text { Equation }\end{array}$} & \multicolumn{3}{|c|}{ BREXIT—24 June 2016} & \multicolumn{3}{|c|}{$\begin{array}{l}\text { Trump's Election- } \\
8 \text { November } 2016\end{array}$} \\
\hline & $\begin{array}{l}\text { Hong } \\
\text { Kong }\end{array}$ & $\begin{array}{l}\text { Mainland } \\
\text { China }\end{array}$ & Taiwan & $\begin{array}{l}\text { Hong } \\
\text { Kong }\end{array}$ & $\begin{array}{l}\text { Mainland } \\
\text { China }\end{array}$ & Taiwan \\
\hline$\alpha_{i}$ & $\begin{array}{l}-0.0177 \\
(0.6779)\end{array}$ & $\begin{array}{l}0.0921 \\
(0.0614)^{\text {*1*k }}\end{array}$ & $\begin{array}{l}-0.0147 \\
(0.6352)\end{array}$ & $\begin{array}{l}-0.0097 \\
(0.7971)\end{array}$ & $\begin{array}{l}0.0937 \\
(0.0214)^{* *}\end{array}$ & $\begin{array}{l}0.0031 \\
(0.8185)\end{array}$ \\
\hline$\beta_{i}$ & $\begin{array}{c}0.2341 \\
(0.000)^{*}\end{array}$ & $\begin{array}{l}0.1282 \\
(0.003)^{*}\end{array}$ & $\begin{array}{c}0.1558 \\
(0.000)^{*}\end{array}$ & $\begin{array}{c}0.2350 \\
(0.000)^{*}\end{array}$ & $\begin{array}{l}0.1303 \\
(0.0035)^{*}\end{array}$ & $\begin{array}{l}0.1648 \\
(0.000)^{*}\end{array}$ \\
\hline$\delta$ & $\begin{array}{l}0.0709 \\
(0.274)\end{array}$ & $\begin{array}{l}-0.0664 \\
(0.2826)\end{array}$ & $\begin{array}{c}0.0395 \\
(0.4176)\end{array}$ & $\begin{array}{l}0.0796 \\
(0.2031)\end{array}$ & $\begin{array}{l}-0.0890 \\
(0.1336)\end{array}$ & $\begin{array}{l}0.0342 \\
(0.4358)\end{array}$ \\
\hline \multicolumn{7}{|c|}{ Variance equation } \\
\hline$\omega$ & $\begin{array}{l}-0.0729 \\
(0.000)^{*}\end{array}$ & $\begin{array}{c}-0.0732 \\
(0.000)^{*}\end{array}$ & $\begin{array}{l}-0.0159 \\
(0.1465)\end{array}$ & $\begin{array}{c}-0.0553 \\
(0.000)^{*}\end{array}$ & $\begin{array}{l}-0.0760 \\
(0.000)^{*}\end{array}$ & $\begin{array}{l}0.0295 \\
(0.000)^{*}\end{array}$ \\
\hline$\alpha_{j}$ & $\begin{array}{c}0.1047 \\
(0.000)^{*}\end{array}$ & $\begin{array}{c}0.1066 \\
(0.000)^{*}\end{array}$ & $\begin{array}{c}0.0106 \\
(0.4545)\end{array}$ & $\begin{array}{l}0.0807 \\
(0.000) *\end{array}$ & $\begin{array}{c}0.1079 \\
(0.000)^{*}\end{array}$ & $\begin{array}{l}-0.048 \\
(0.000)^{*}\end{array}$ \\
\hline$\gamma$ & $\begin{array}{l}-0.0378 \\
(0.002)^{*}\end{array}$ & $\begin{array}{c}0.0335 \\
(0.000)^{*}\end{array}$ & $\begin{array}{l}-0.1057 \\
(0.000)^{*}\end{array}$ & $\begin{array}{l}-0.0503 \\
(0.000)^{*}\end{array}$ & $\begin{array}{c}0.0354 \\
(0.000)^{*}\end{array}$ & $\begin{array}{l}-0.084 \\
(0.000)^{*}\end{array}$ \\
\hline$\beta_{j}$ & $\begin{array}{c}0.9610 \\
(0.000)^{*}\end{array}$ & $\begin{array}{c}0.9972 \\
(0.000)^{*}\end{array}$ & $\begin{array}{c}0.9811 \\
(0.000)^{*}\end{array}$ & $\begin{array}{l}0.9556 \\
(0.000)^{*}\end{array}$ & $\begin{array}{c}0.9986 \\
(0.000)^{*}\end{array}$ & $\begin{array}{l}0.9871 \\
(0.000)^{*}\end{array}$ \\
\hline$\varphi$ & $\begin{array}{l}-0.0282 \\
(0.002)^{*}\end{array}$ & $\begin{array}{l}-0.0100 \\
(0.0861)\end{array}$ & $\begin{array}{l}-0.0110 \\
(0.1984)\end{array}$ & $\begin{array}{r}-0.0519 \\
(0.002)^{*}\end{array}$ & $\begin{array}{l}-0.0080 \\
(0.2480)\end{array}$ & $\begin{array}{l}-0.017 \\
(0.007)^{*}\end{array}$ \\
\hline
\end{tabular}

Source: The authors.

Notes: $\omega$ (constant); $\alpha$ (Impact of magnitude of a shock(size) and $\beta$ Garch effect. Persistence of past volatility (past volatility explains current volatility); $\gamma$ (impact of sign of shock); if the coefficient is negative, there is a leverage effect: bad news have more of an impact than good news on the same size; $\varphi$ (dummy variable). Volatility estimations were not adjusted to include the control variables as the coefficients were not found to be statistically significant. *1\% significance level, **5\% significance level, *** 10\% significance level.

The EGARCH model outcomes do not seem to be affected by the inclusion of the EPU index in the estimation, and the research outcomes confirm that Hong Kong and Taiwan seem to react to negative news, whereas China is more sensitive to the occurrence of positive news. The markets do not seem to show a significant reaction to Brexit and Trump's election as the $\delta$ coefficient measuring for each event is statistically insignificant; this is also the case for $\theta$ that captures the impact of the EPU index. The core research findings indicate that Brexit and Trump's election do not seem to be generating significant levels of volatility in the 
Table 7. Volatility Model Without Economic Policy Uncertainty

\begin{tabular}{|c|c|c|c|c|c|c|}
\hline $\begin{array}{l}\text { Leadership } \\
\text { Event- } \\
\text { With EPU } \\
\text { Index }\end{array}$ & BREX & KIT-24 June & 2016 & $\begin{array}{l}\text { Tru } \\
8 \wedge\end{array}$ & $\begin{array}{l}\text { mp's Electio } \\
\text { Jovember } 2\end{array}$ & 016 \\
\hline $\begin{array}{l}\text { Mean } \\
\text { Equation }\end{array}$ & $\begin{array}{l}\text { Hong } \\
\text { Kong }\end{array}$ & $\begin{array}{l}\text { Mainland } \\
\text { China }\end{array}$ & Taiwan & $\begin{array}{l}\text { Hong } \\
\text { Kong }\end{array}$ & $\begin{array}{c}\text { Mainland } \\
\text { China }\end{array}$ & Taiwan \\
\hline$\alpha_{i}$ & $\begin{array}{c}-0.0130 \\
(0.7398)\end{array}$ & $\begin{array}{l}0.0888 \\
(0.0769)^{* * * *}\end{array}$ & $\begin{array}{c}-0.0070 \\
(0.8130)\end{array}$ & $\begin{array}{c}-0.0072 \\
(0.8485)\end{array}$ & $\begin{array}{l}0.0935 \\
(0.0194)^{* *}\end{array}$ & $\begin{array}{l}0.0255 \\
(0.0335)^{* *}\end{array}$ \\
\hline$\beta_{i}$ & $\begin{array}{c}0.4768 \\
(0.000)^{*}\end{array}$ & $\begin{array}{c}0.1782 \\
(0.000)^{*}\end{array}$ & $\begin{array}{c}0.2525 \\
(0.000)^{*}\end{array}$ & $\begin{array}{c}0.2303 \\
(0.000)^{*}\end{array}$ & $\begin{array}{c}0.1214 \\
(0.007)^{*}\end{array}$ & $\begin{array}{c}0.1430 \\
(0.000)^{*}\end{array}$ \\
\hline$\delta$ & $\begin{array}{c}0.0576 \\
(0.3160)\end{array}$ & $\begin{array}{c}-0.0699 \\
(0.252)\end{array}$ & $\begin{array}{c}-0.0008 \\
(0.9860)\end{array}$ & $\begin{array}{c}0.0786 \\
(0.2079)\end{array}$ & $\begin{array}{l}-0.0836 \\
(0.1558)\end{array}$ & $\begin{array}{c}0.0127 \\
(0.7745)\end{array}$ \\
\hline$\theta$ & $\begin{array}{c}0.0000 \\
(0.9871)\end{array}$ & $\begin{array}{c}0.0002 \\
(0.772)\end{array}$ & $\begin{array}{c}0.0003 \\
(0.5286)\end{array}$ & $\begin{array}{c}-0.0005 \\
(0.4194)\end{array}$ & $\begin{array}{c}-0.0002 \\
(0.7135)\end{array}$ & $\begin{array}{c}0.0002 \\
(0.5095)\end{array}$ \\
\hline & & Varia & iance equat & & & \\
\hline$\omega$ & $\begin{array}{c}-0.0853 \\
(0.000)^{*}\end{array}$ & $\begin{array}{l}-0.0823 \\
(0.000)^{*}\end{array}$ & $\begin{array}{c}-0.0017 \\
(0.8662)\end{array}$ & $\begin{array}{c}-0.0534 \\
(0.000)^{*}\end{array}$ & $\begin{array}{c}-0.0725 \\
(0.000)^{*}\end{array}$ & $\begin{array}{c}0.0356 \\
(0.000) *\end{array}$ \\
\hline$\alpha_{j}$ & $\begin{array}{l}0.1127 \\
(0.000)^{*}\end{array}$ & $\begin{array}{c}0.1198 \\
(0.000)^{*}\end{array}$ & $\begin{array}{c}-0.0107 \\
(0.3992)\end{array}$ & $\begin{array}{c}0.0772 \\
(0.000)^{*}\end{array}$ & $\begin{array}{c}0.1032 \\
(0.000)^{*}\end{array}$ & $\begin{array}{c}-0.0603 \\
(0.000)^{*}\end{array}$ \\
\hline$\gamma$ & $\begin{array}{c}-0.0486 \\
(0.002)^{*}\end{array}$ & $\begin{array}{c}0.0270 \\
(0.003)^{*}\end{array}$ & $\begin{array}{r}-0.0950 \\
(0.000)^{*}\end{array}$ & $\begin{array}{c}-0.0444 \\
(0.000)^{*}\end{array}$ & $\begin{array}{c}0.0361 \\
(0.000)^{*}\end{array}$ & $\begin{array}{c}-0.0859 \\
(0.000) *\end{array}$ \\
\hline$\beta_{j}$ & $\begin{array}{c}0.9662 \\
(0.000)^{*}\end{array}$ & $\begin{array}{c}0.9958 \\
(0.000)^{*}\end{array}$ & $\begin{array}{c}0.9808 \\
(0.000)^{*}\end{array}$ & $\begin{array}{c}0.9609 \\
(0.000)^{*}\end{array}$ & $\begin{array}{c}0.9982 \\
(0.000)^{*}\end{array}$ & $\begin{array}{c}0.9848 \\
(0.000)^{*}\end{array}$ \\
\hline$\varphi$ & $\begin{array}{l}-0.0236 \\
(0.0157)^{\text {** }}\end{array}$ & $\begin{array}{l}-0.0119 \\
(0.0771)^{* * * * *}\end{array}$ & $\begin{array}{r}-0.0067 \\
(0.3257)\end{array}$ & $\begin{array}{c}-0.0469 \\
(0.002)^{*}\end{array}$ & $\begin{array}{c}-0.0075 \\
(0.242)\end{array}$ & $\begin{array}{c}-0.0190 \\
(0.002)^{*}\end{array}$ \\
\hline$\rho$ & $\begin{array}{c}0.0046 \\
(0.000) *\end{array}$ & $\begin{array}{c}0.0014 \\
(0.1316)\end{array}$ & $\begin{array}{c}0.0043 \\
(0.000)^{*}\end{array}$ & $\begin{array}{l}0.0014 \\
(0.134)\end{array}$ & $\begin{array}{c}0.0025 \\
(0.004)^{*}\end{array}$ & $\begin{array}{c}0.0026 \\
(0.000)^{*}\end{array}$ \\
\hline
\end{tabular}

Source: The authors.

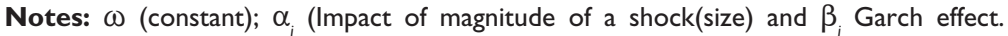
Persistence of past volatility (past volatility explains current volatility); $\gamma$ (impact of sign of shock); if the coefficient is negative, there is a leverage effect: bad news has more of an impact than good news on the same size; $\varphi$ (dummy variable); $\rho$ (EPU variable). Volatility estimations were not adjusted to include the control variables as coefficients were not found to be statistically significant. *1\% significance level, $* * 5 \%$ significance level, $* * * 10 \%$ significance level.

GCR. The results are not surprising as over the years China has managed to remain quite isolated to global shocks with the government exercising high levels of intervention in its capital markets. While being gradually reformed, the Chinese financial markets are still rather insulated from major international shocks. These results seem to confirm the strong position of China in the international context and that might help the country 
to weather economic policies from developed economies that aim to harm its global position.

\section{Critical Insights on China's Stock Holding Patterns}

During the 1980s, the Chinese stock market started its development process with the introduction of a legal framework that sought to allow companies to issue shares and to encourage them to start local trading activities by selling small amount of shares to the public. In December 1990, the Shanghai and Shenzhen stock markets started to operate (again in the case of Shanghai after a long period of interruption under Mao's policies) with at the time only eight names listed representing a market capitalisation of USD 500 million. The situation has changed quite dramatically, as by the year 2017, more than 3,000 companies were listed with a market capitalisation of over RMB 50 trillion. A specific feature of the Chinese stock markets is the large representation of the most important Chinese companies that are state-owned, including large banks and oil companies that are controlled by the Central Government through the State-Owned Assets Supervision and Administration Commission of the ruling State Council (SASAC), which appoints CEOs and makes decisions in terms of large investments (Andreosso-O'Callaghan \& Gottwald, 2013; Firth, Gao, Shen, \& Zhang, 2016; Gang \& Hope, 2013). Through state ownership, the Chinese SOEs enjoy massive state support that insulates them from competition while facilitating the government growth policies. Shanghai has historically been home to China's most prominent large capitalised companies. On the other hand, Shenzhen is host to smaller and midcapitalised companies with a higher level of private ownership. Chinese SOEs still dominate the enterprises landscape, with SOEs representing around 70 per cent of the Chinese top-500 enterprises, 94 per cent of assets and 88 per cent of profits (OECD, 2017). They contribute to 93 per cent of the taxes generated, and they employ 89 per cent of the total workforce in the Chinese top-500 enterprises. A further breakdown of the outlined figures shows that in the manufacturing sector, SOEs account for about 50 per cent of firms, contributing 61 per cent of the total profit. In the services sector, SOEs account for 61 per cent of the firms, with 93 per cent of assets and 92 per cent of profits among the top-500 enterprises (Gang, Yang, \& Janus, 2009; OECD, 2017). At the global level and thanks to the Chinese Government 'Go Global Strategy', Chinese SOEs are becoming more and more significant, and they show high levels of concentration 
in strategic sectors that help and serve specific government purposes. The significant presence of the Chinese government in these stock markets implies that price fluctuations in these stock exchanges are heavily dependent on the government moves and in particular on its short-term speculative strategies and as such, macroeconomic fundamentals do not appear to be impacting upon China's major stock markets behaviour. Neither the Shanghai nor the Shenzhen stock exchange market is considered as being a 'developed market', and the two markets still need to engage in further modernisation processes that align them with international practices. Important areas of concern relate to the markets insufficient levels of transparency and lower financial reporting standards that pose serious limitations to the potential of developing analytical reports based on their companies' financial results (Gang \& Hope, 2013; OECD, 2017). Moreover, there is a serious disconnect between share valuations and financial results, a disconnect which is partly explained by the dominance of these SOEs in these stock exchanges, and therefore by the government's political goals, often disregarding the interest of minority shareholders. Another aspect that needs to be considered is market instability associated with the deterioration in the stock exchanges, a phenomenon exacerbated by corruption among stock market regulators; insider trading is common practice, and flows of personnel between the China Securities Regulatory Commission (CSRC) and the firms that trade in shares are unrestricted, leading to obvious conflicts of interest. To sum up, the characteristics, dynamics and stock holding patterns of the Chinese stock markets offer some interesting insights that help support the main empirical outcomes of this study indicating that the Chinese stock exchanges are relatively sheltered from EPU derived from Brexit and from the election of Donald Trump; Chinese stock markets behaviour is carefully designed and framed by the Chinese government.

\section{Conclusions and Policy Implications}

In general, the research findings highlight the importance for world leading economies to maintain political stability, as their economic policies can generate significant levels of anxiety and uncertainty. There is no doubt that the GCR needs to monitor unfolding events in two of the world most developed economies, as China trade interests are quite linked to the USA and to the EU. However, in the context of the Greater China Region, the main research findings suggest that Brexit and the US election are not generating significant variations on market returns performance and the impact of EPU in the global context appears to be insignificant. 
China's stocks markets do not seem to be panicking and overreacting to recent major world events. These results seem to confirm China's historical behaviour regarding international shocks in so far as the country has managed to remain unscathed, an outcome that can be explained by the tight control exercised by the government on its capital markets. Further research in the area should consider looking at causal effects running from international EPU; this would offer an in-depth understanding of the key political events that might have a greater impact on stock market performance in the Chinese context and of the trade channel and its spillover effects to the country's main macroeconomic fundamentals and its capital markets.

\section{Declaration of Conflicting Interests}

The authors declared no potential conflicts of interest with respect to the research, authorship and/or publication of this article.

\section{Funding}

The authors received no financial support for the research, authorship and/or publication of this article.

\section{Appendix}

Figure AI. Volatility Patterns on Studied Variables

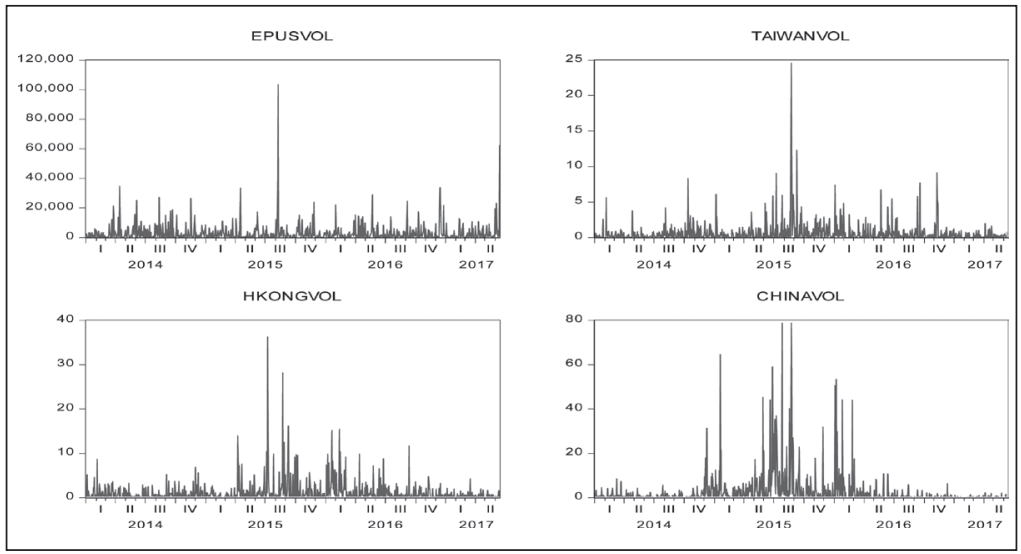

(Appendix continued) 
(Appendix continued)

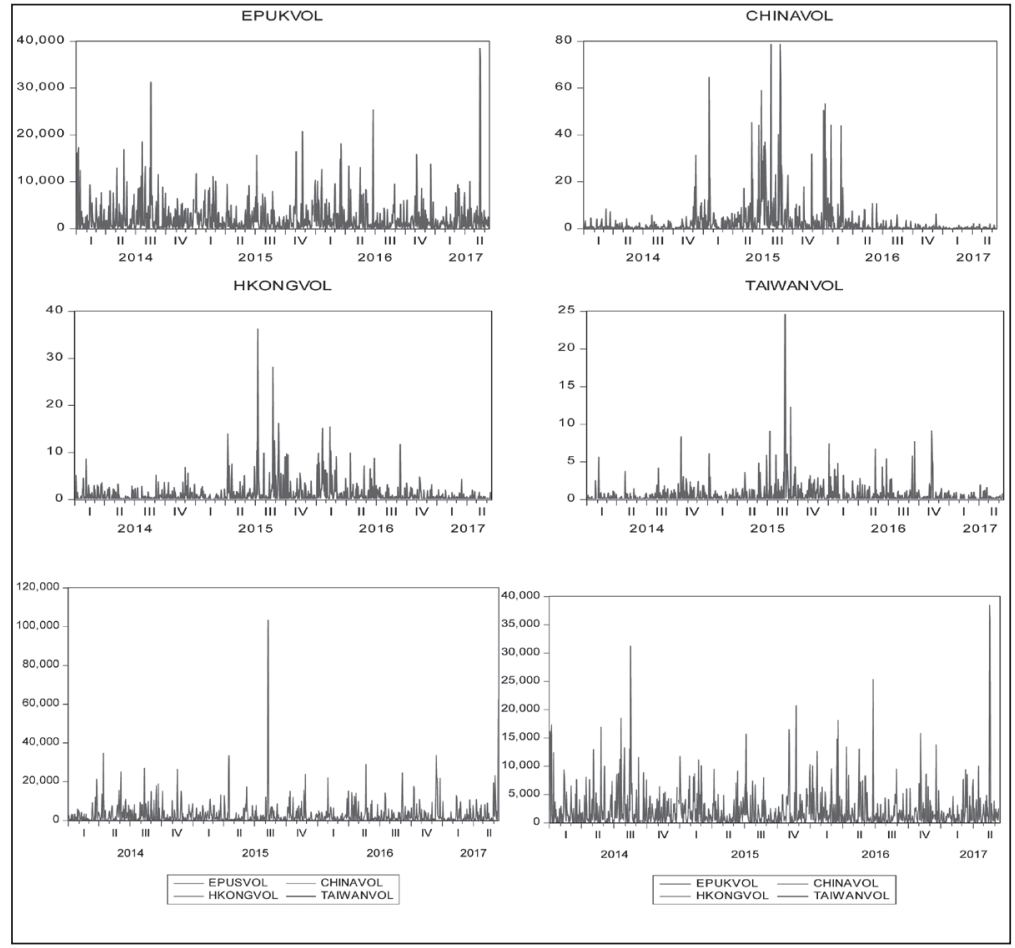

Source: The authors.

\section{Note}

1. Macau is not included as part of this study because it does not have a stock market. However, companies can seek listing in the Hong Kong Stock Exchange, as both regions financial regulatory authorities cooperate on issues of mutual concern.

\section{References}

Aggarwal, R., Inclan, C., \& Leal, R. (1999). Volatility in emerging stock markets. Journal of Financial and Quantitative Analysis, 34(1), 33-55.

Anatonakakis, N., Chatziantoniou, I., \& Filis, G. (2013). Dynamic co-movement of stock market returns, implied volatility and policy uncertainty. Economics Letters, 120(1), 87-92.

Andreosso-O'Callaghan, B., \& Gottwald, J. C. (2013). How red is China's red capitalism? Continuity and change in China's financial services sector during the global crisis. Asia Pacific Business Review, 19(4), 444-460. 
Arouri, M., Estay, C., Rault, C., \& Roubaud, D. (2016). Economic policy uncertainty and stock markets: Long-run evidence from the US. Finance Research Letters, 18(C), 136-141.

Baker, S., Bloom, N., \& Davis, S. (2012). Measuring economic policy uncertainty (Working Paper Series). Stanford University. Retrieved from https://papers. ssrn.com/sol3/papers.cfm?abstract id=2009451

- (2016). Measuring economic policy uncertainty. Quarterly Journal of Economics, 131(4), 1539-1636.

Benacek, V., Lenihan, H., Andreosso-O'Callaghan, B., Michalikova, E., \& Kan, D. (2014). Political risk, institutions and foreign direct investment: How do they relate in various European countries? The World Economy, 37(5), 625-653.

Bilson, C. M., Brailsford, T., \& Hooper, V. C. (2002). The explanatory power of political risk in emerging markets. International Review of Financial Analysis, 11(1), 1-27.

Bin, L. (2015). Political leadership events and stock market reactions: Evidence from the Greater China Region. Journal of Accounting and Finance, 15(8), 81-94.

Bin, F. S., Blenman, L., \& Chen, D. H (2004). Valuation impact of currency crises: Evidence from the ADR market. International Review of Financial Analysis, 13(4), 411-432.

Bittlingmayer, G. (1998). Output, stock volatility, and political uncertainty in a natural experiment: Germany, 1880-1940. Journal of Finance, 53(6), 2243-2258. Retrieved from http://dx.doi.org/10.1111/0022-1082.00090

Bloom, N. (2009). The impact of uncertainty shocks. Econometrica, 77(3), 623-685.

Brewer, T. L. (1981). Political risk assessment for foreign direct investment decisions: Better methods for better results. Columbia Journal of World Business, 16(1), 5-12.

Brogaard, J., \& Detzel, A. (2015). The asset-pricing implications of government economic policy uncertainty. Management Science, 61(1), 3-18.

Chan, Y., \& Wei, J. (1996). Political risk and stock price volatility: The case of Hong Kong. The Pacific-Basin Finance Journal, 4(2), 259-275.

Clark, E. (1997). Valuing political risk. Journal of International Money and Finance, 16, 477-490. Retrieved from http://dx.doi.org/10.1016/S02615606(97)00008-9

Clark, E., \& Tunaru, R. (2003). Quantification of political risk with multiple dependent sources. Journal of Economics and Finance, 27(2), 125-135. Retrieved from http://dx.doi.org/10.1007/BF02827214

- (2005). The evolution of international political risk 1956-2001. Retrieved from http://repec.org/mmfc05/paper37.pdf

Dopke, J., \& Pierdzioch, C. (2006). Politics and the stock market: Evidence from Germany. European Journal of Political Economy, 22(4), 925-943.

Firth, M., Gao, J. Shen, J., \& Zhang, Y. (2016). Institutional stock ownership and firms' cash dividend policies: Evidence from China. Journal of Banking and Finance, 65, 91-107. 
Fong, W. M., \& Koh, S. K. (2002). The political economy of volatility dynamics in the Hong Kong market. Asia-Pacific Financial Markets, 9(3-4), 259-282.

Gang, F., \& Hope, N. (2013). The role of state-owned enterprises in the Chinese economy. US-China 2022. US-China economic relations in the next ten years. Part II (Chapter 16). Retrieved from https://www.chinausfocus. com/2022/index-page_id=1480.html

Geng, X., Yang, X., \& Janus, A. (2009). State-owned enterprises in China: Reform dynamics and impacts. In R. Garnaut, L. Song \& W. T. Woo (Eds.), China's new place in a world in crisis: Economic, geopolitical and environmental dimensions (pp. 155-178). Canberra: ANU Press.

Hammoudeh, S., \& McAleer, M. (2015). Advances in financial risk management and economic policy uncertainty: An overview. Internal Review of Economics and Finance, 40(C), 1-7.

Kang, W., \& Ratti, R. A. (2015). Oil shocks, policy uncertainty, and stock returns in China. Economics of Transition, 23(4), 657-676.

Khalid, A. M., \& Rajaguru, G. (2010). The impact of political events on financial market volatility: Evidence using a Markov switching process (Working Paper Series No. 43). Australia: The Globalisation and Development Centre, Bond University. Retrieved from https:/www.researchgate.net/publication/ 47929666_The_impact_of_political_events_on_financial_market_volatility_ Evidence_using_a_Markov_Switching process

Kim, Y., Nam, J., \& Wynne, K. J. (2009). An event study approach to shocks in gold prices on hedged and non-hedged gold companies. Investment Management and Financial Innovations, 6(2), 112-119.

Laverde, J. C. F., Varua, M. E., \& Garces-Ozanne, A. (2009) Understanding crime, political uncertainty and stock market returns. World Economics, 10(2), 109-116.

Li, X. M., \& Peng, L. (2017). US economic policy uncertainty and co-movements between Chinese and US stock markets. Economic Modelling, 61, 27-39.

Lin, C. T., \& Wang, Y. H. (2005). An analysis of political changes on Nikkei 225 stock returns and volatilities. Annuals of Economics and Finance, 6(1), $169-183$.

Liu, L., \& Zhang, T. (2015). Economic policy uncertainty and stock market volatility. Finance Research Letters, 15(C), 99-105.

Mahmood, S., Irfan, M., Iqbal, S., Kamran, M., \& Ijaz, A. (2014). Impact of political events on stock market: Evidence from Pakistan. Journal of Asian Business Strategy, 4(12), 163-174.

Manzoor, H. (2013). Impact of Pak-US relationship news on KSE-100 Index. Basic Research Journal of Business Management and Accounts, 2(2), $1-24$.

Nazir, M. S., Younus, H., Kaleem, A., \& Anwar, Z. (2014). Impact of political events on stock market returns: Empirical evidence from Pakistan. Journal of Economic and Administrative Sciences, 30(1), 60-78.

Nelson, D. B. (1991). Conditional heteroskedasticity in asset returns: A new approach. Econometrica, 59(2), 347-370. 
OECD. (2017). The size and sectoral distribution of state-owned enterprises. Paris: OECD Publishing. Retrieved from http://dx.doi.org/10.1787/ 9789264280663-en

Root, F. (1972). Analysing political risks in international business. In A. Kapoor \& P. D. Grub (Eds.), Multinational enterprise in transition (pp. 354-365). Princetown: Darwin.

Rosier, K., O'Connor, S., \& Cuevas, R. (2016). Taiwan's economy amid political transition. U.S.-China economic and security review commission. Staff Research Report. Retrieved from https:/www.uscc.gov/sites/default/files/ Research/Taiwan\%27s\%20Economy\%20amid\%20Political\%20Transition. pdf

Simon, J. D. (1982). Political risk assessment: Past trends and future prospects. Columbia Journal of World Business, 17(3), 62-70.

Soultanaeva, A. (2008). Impact of political news on the Baltic State stock markets. Retrieved from http://ideas.repec.org/p/hhs/umnees/0735.html

Suleman, M. T. (2012). Stock market reactions to good and bad political news. Asian Journal of Finance and Accounting, 4(1), 299-312.

Tan, O. G., \& Gannon, G. L. (2002). Information effect of economic news: SPI futures. International Review of Financial Analysis, 11, 467-489. Retrieved from http://dx.doi.org/10.1016/S1057-5219(02)00065-0

Tanaka, H. (2017). How to manage geopolitical instability in East Asia. East Asia insights: Toward community building. Japan Center for International Exchange. Retrieved from http://www.jcie.or.jp/insights/11-4.pdf

Wang, Y., Chen, C. R., \& Huang, Y. S. (2014). Economic policy uncertainty and corporate investment: Evidence from China. The Pacific-Basin Finance Journal, 26, 227-243. 